\title{
SISTEM PENDUKUNG KEPUTUSAN PENYALURAN BANTUAN MODAL USAHA PUAP (PENGEMBANGAN USAHA AGRIBISNIS PEDESAAN) DI KABUPATEN INDRAGIRI HILIR
}

\author{
${ }^{1}$ Fiendra Adha R., ${ }^{2}$ Muh. Rasyid Ridha \\ 1,2, Program Studi Sistem Informasi, Fakultas Teknik dan Ilmu Komputer \\ Universitas Islam Indragiri (UNISI) \\ Jl. Provinsi No. 01 Tembilahan Hulu, Indragiri Hilir, Riau - Indonesia \\ Email:fiendraa03@gmail.com, rasyid4sky@gmail.com
}

\begin{abstract}
PUAP merupakan bentuk fasilitas bantuan modal usaha bagi petani anggota, baik petani pemilik, petani penggarap, buruh tani maupun rumah tangga tani yang dikoordinasikan oleh Gabungan Kelompok Tani (Gapoktan). Badan Pelaksana Penyuluhan dan Ketahanan Pangan Kabupaten Indragiri Hilir merupakan kelembagaan penyuluhan Pertanian dan Ketahanan Pangan di Kabupaten Indragiri Hilir. Dalam melaksanakan kegiatan operasionalnya BP2KP juga menagani permasalahan peyaluran bantuan modal PUAP untuk Gapoktan yang ada di Kabupaten Indragiri Hilir. pihak BP2KP memiliki sistem evaluasi dan seleksi Gapoktan sebelumnya yang hanya menekankan pada siapa yang mengajukan lebih lama tanpa mempertimbangkan kemampuan dan kesanggupan dari Gapoktan dalam mengelola bantuan modal itu tadi. Sistem ini tentunya tidak menguntungkan bagi BP2KP, karena kriteria yang digunakan dalam evaluasi dan seleksi Gapoktan belum menerapkan kriteria yang ada dalam aturan penyaluran dana PUAP yang sangat mempengaruhi penilaian dan dapat digunakan untuk menilai kinerja suatu Gapoktan. Maka dari itu, diperlukan sebuah sistem informasi yang baik pada proses pemilihan Gapoktan untuk memudahkan dalam menentukan Gapoktan mana yang layak diberikan bantuan modal usaha, dalam hal ini digunakan sistem pendukung keputusan dengan metode Analytical Hierarchy Process (AHP) merupakan sebuah metode yang dianggap baik untuk melalukan proses pengolahan data hasil survey. Metode tersebut dianggap baik karena dapat membandingkan antar kriteria dan juga antar alternatif yang telah dipilih. Hasil akhir dari penelitian ini yaitu Gapoktan yang menjadi prioritas utama untuk dijadikan sebagai bahan rekomendasi penerima penyaluran bantuan modal usaha pengembangan usaha agribisnis pedesaan di BP2KP Kabupaten Indragiri Hilir yaitu Maju Bersama adalah rangking pertama dengan nilai prioritas 0.379 atau 37,9\%. Dan kriteria eigen tertinggi adalah Memiliki SDM untuk Mengelola Usaha Agribisnis (SDM) dengan nilai 0.648 atau $64,8 \%$.
\end{abstract}

Kata Kunci : Sistem Pendukung Keputusan, Analytical Hierarchy Process, PUAP, Gapoktan, BP2KP Kabupaten Indragiri Hilir

\section{PENDAHULUAN}

Pemilihan Gapoktan perlu dilakukan untuk mendapatkan Gapoktan yang benar-benar mampu mengelola dengan baik bantuan modal yang diberikan secara konsisten. Proses pemilihan Gapoktan dilakukan dengan cara melakukan evaluasi terhadap Gapoktan dan membandingkannya dengan menggunakan ukuran dan kriteria yang sesuai. Bobot dari kriteria dan indikator kinerja Gapoktan pada akhirnya dapat digunakan untuk menyeleksi dan mengevaluasi Gapoktan sehingga dapat diketahui Gapoktan yang terpilih. Maka dari itu, diperlukan sebuah sistem informasi yang baik pada proses pemilihan Gapoktan untuk memudahkan dalam menentukan Gapoktan mana yang layak diberikan bantuan modal usaha, dalam hal ini digunakan sistem pendukung keputusan (SPK).

SPK bagian dari sistem informasi berbasis komputer, termasuk sistem berbasis pengetahuan yang dipakai untuk mendukung pengambilan keputusan dalam suatu organisasi. Sistem pengambilan keputusan dirancang untuk mendukung seluruh tahap pengambilan keputusan mulai 
dari mengidentifikasi masalah, menemukan data relevan, menentukan pendekatan yang digunakan dalam proses pengambilan keputusan, mengevaluasi pemilihan alternatif.

Sistem pendukung keputusan dapat membantu melakukan penilaian dalam menentukan kriteria-kriteria pemilihan Gapoktan. Melakukan perubahan kriteria, dan perubahan nilai bobot hal ini berguna untuk memudahkan pengambilan keputusan yang terkait dengan pemilihan Gapoktan tersebut, sehingga akan didapatkan keluaran sistem yang layak untuk dipertimbangkan. Metode AHP merupakan merupakan sistem pendukung keputusan dengan menggunakan model matematis. AHP membantu dalam menentukan prioritas dari beberapa kriteria dengan melakukan analisa perbandingan berpasangan dari masing-masing kriteria.

\section{TINJAUAN PUSTAKA}

\subsection{Konsep Sistem Pendukung Keputusan}

Sistem Pendukung Keputusan atau Decision Support System (DSS) merupakan sistem informasi interaktif yang menyediakan informasi, pemodelan dan memanipulasi data. Sistem itu digunakan untuk membantu pengambilan keputusan dalam situasi yang semiterstuktur dan situasi yang tidak terstruktur, dimana tak seorangpun tahu secara pasti bagaiman keputusan seharusnya dibuat (Kusrini, 2007).

\subsubsection{Sistem}

Subsistem-subsistem saling berinteraksi dan saling berhubungan membentuk satu kesatuan sehingga tujuan atau sasaran sistem tersebut dapat tercapai. Interaksi dari subsistem-subsistem sedemikian rupa,, sehingga dicapai suatu suatu kesatuan yang terpadu atau terintegrasi (integrated). Anda dapat membayangkan bagaiman seandainya sistem komputer yang anda miliki, masing-masing komponennya saling bekerja sendiri-sendiri tidak terintegrasi, maka tujuan dari sistem komputer tersebut tidak akan tercapai, (Hartono, 2005).

Suatu sistem dapat terdiri dari sistem-sistem bagaian (subsystems). Sebagai misal, sistem komputer dapat terdiri dari subsistem perangkat keras dan subsistem perangkat lunak. Masingmasing subsistem dapat terdiri dari subsistem-subsistem yang lebih kecil lagi atau terdiri dari komponen-komponen. Subsistem perangkat keras (hardware) dapat terdiri dari alat masukan, alat pemroses, alat keluaran dan simpanan luar. Dengan kata lain suatu sistem terdiri dari sejumlah komponen yang saling berinteraksi, yang artinya saling bekerja membentuk satu kesatuan, (Hartono, 2005).

\subsubsection{Sistem Pendukung Keputusan}

Sistem pendukung keputusan merupakan suatu sistem interaktif yang mendukung keputusan dalam proses pengambilan keputusan melalui alternatif-alternatif yang diperoleh dari hasil pengolahan dat, informasi dan rancangan model, (Herdiyanti \& Widianti, 2013). Konsep Sistem Pendukung Keputusan pertama kali diperkenalkan pada awal tahun 1970-an oleh Michael S.Scoot Morton dengan istilah Management Decision System. Konsep sistem pendukung keputusan ditandai dengan sistem interaktif berbasis komputer yang membantu pengambilan keputusan memanfaatkan data dan model untuk menyelesaikan masalah-masalah yang tidak terstruktur, (Iwan \& Lirien, 2012).

Sebagai sebuah sistem, SPK (Sistem Pendukung Keputusan) juga memiliki komponen yang agak berbeda dengan komponen SIA (Sistem Informasi Akuntansi) dan SIM (Sistem Informasi Manajemen). Komponen SPK pada dasarnya adalah sebagai berikut: 1) Basis data, yang berasal dari sumber internal (dicatat oleh perusahaan dari berbagai transaksi yang selama ini terjadi) dan dari sumber eksternal (diambil oleh perusahaan dari diluar perusahaan, misalnya data industri, data statistik,dan data peraturan pemerintah). 2) Model dan pengetahuan mengenai masalah dan keputusan yang harus diambil. Dan 3) Berbagai perangkat analisis yang digunakan untuk mencari jalan keluar terbaik. 


\subsection{Konsep Model Analytical Hierarchy Process (AHP)}

AHP memiliki banyak keunggulan dalam menjelaskan proses pengambilan keputusan. Salah satunya adalah dapat digambarkan secara grafis sehingga mudah dipahami oleh semua pihak yang terlibat dalam pengambilan keputusan, (Kusrini, 2007).

Pada dasarnya proses pengambilan keputusan adalah memilih suatu alternatif. Peralatan utama AHP adalah sebuah hierarki fungsional dengan input utamanya persepsi manusia. Keberadaan hierarki memungkinkan dipecahnya masalah kompleks atau tidak terstruktur dalam sub-sub masalah, lalu menyusunnya menjadi suatu bentuk hierarki.

AHP dikembangkan Dr. Thomas L. Saaty dari Wharton School of Business pada tahun 1970-an untuk mengorganisasikan informasi dan judgement dalam memilih alternatif yang paling disukai. Pada dasarnya AHP adalah metode untuk memecahkan suatu masalah yang kompleks dan tidak terstruktur kedalam kelompoknya, mengatur kelompok-kelompok tersebut kedalam suatu susunan hierarki, memasukkan nilai numerik sebagai pengganti persepsi manusian dalam melakukan perbandingan relatif dan akhirnya dengan suatu sintesis ditentukan elemen yang mempunyai prioritas tertinggi, (Tominanto, 2012).

Pada dasarnya, langkah-langkah dalam metode AHP meliputi:

Mendefenisikan masalah dan menentukan solusi yang diinginkan, lalu menyusun hierarki dari permasalahan yang dihadapi. Penyusun hierarki adalah dengan menetapkan tujuan yang merupakan sasaran sistem secara keseluruhan pada level teratas.

Menentukan prioritas elemen: a) Langkah pertama dalam menentukan prioritas elemen adalah membuat perbandingan pasangan, yaitu membandingkan elemen secara berpasangan sesuai kriteria yang diberikan. b) Matriks perbandingan berpasangan diisi menggunakan bilangan untuk merepresentasikan kepentingan relatif dari suatu elemen terhadap elemen yang lainnya.

Sintesis. Pertimbangan-pertimbangan terhadap perbandingan berpasangan di sintesis untuk memperoleh keseluruhan prioritas. Hal-hal yang dilakukan dalam langkah ini adalah: a) Menjumlahkan nilai-nilai dari setiap kolom pada matriks. b) Membagi setiap nilai dari kolom dengan total kolom yang bersangkutan untuk memperoleh normalisasi matriks. c) Menjumlahkan nilai-nilai dari setiap basis dan membagikan dengan jumlah elemen untuk mendapatkan nilai rata-rata.

Mengukur Konsistensi. Dalam pembuatan keputusan, penting untuk mengetahui seberapa baik konsistensi yang ada karena kita tidak menginginkan keputusan berdasarkan pertibangan dengan konsistensi yang rendah. Hal-hal yang dilakukan dalam langkah ini adalah: (a) Kalikan setiap nilai pada kolom pertamadengan prioritas relatif elemen pertama, nilai pada kolom kedua prioritas relatif elemen kedua, dan seterusnya. (b) Jumlah setiap baris. (c) Hasil dari penjumlahan baris dibagi dengan elemen prioritas relatif yang bersangkutan. (d) Jumlah hasil bagi di atas dengan banyaknya elemen yang ada, hasil disebut $\lambda$ maks

Hitung cinsistency Index $(\mathrm{Cl})$ dengan rumus:

$\mathrm{Cl}=(\lambda$ maks $-\mathrm{n}) / \mathbf{n}$

Di mana $\mathrm{n}=$ banyaknya elemen

Hitung rasio konsistensi/consistency ratio $(C R)$ dengan rumus:

$\mathrm{CR}=\mathrm{Cl} / \mathrm{RC}$

Di mana $\quad \mathrm{CR}=$ Consistency Ratio

$\mathrm{Cl}=$ Consistency Index

$\mathrm{IR}=$ Indeks Random Consistency

Memeriksa konsistensi hierarki. Jika nilainya lebih dari 10\%, maka penilaian data judgment harus diperbaiki. Namun jika rasio konsistensi ( $\mathrm{Cl} / \mathrm{IR}$ ) kurang atau sama dengan 0,1 , maka hasil perhitungan bisa dinyatakan dengan benar. Daftar indeks Random Konsistensi (IR) bisa dilihat dalam Tabel 2.2 berikut: 
Tabel 2.1 Indeks Random Konsistensi

\begin{tabular}{cc}
\hline Ukuran Matriks & Nilai IR \\
\hline 1,2 & 0.00 \\
3 & 0.58 \\
4 & 0.90 \\
5 & 1.12 \\
6 & 1.24 \\
7 & 1.32 \\
8 & 1.41 \\
9 & 1.45 \\
10 & 1.49 \\
11 & 1.51 \\
12 & 1.48 \\
13 & 1.56 \\
14 & 1.57 \\
15 & 1.59 \\
\hline
\end{tabular}

\section{METODOLOGI PENELITIAN}

\subsection{Metodologi Penelitian}

Flowchart penelitian Sistem Pendukung Keputusan Penyaluran Bantuan Modal Usaha PUAP (Pengembangan Usaha Agribisnis Pedesaan) Di Kabupaten Indragiri Hilir dapat dilihat pada gambar 3.1 berikut:

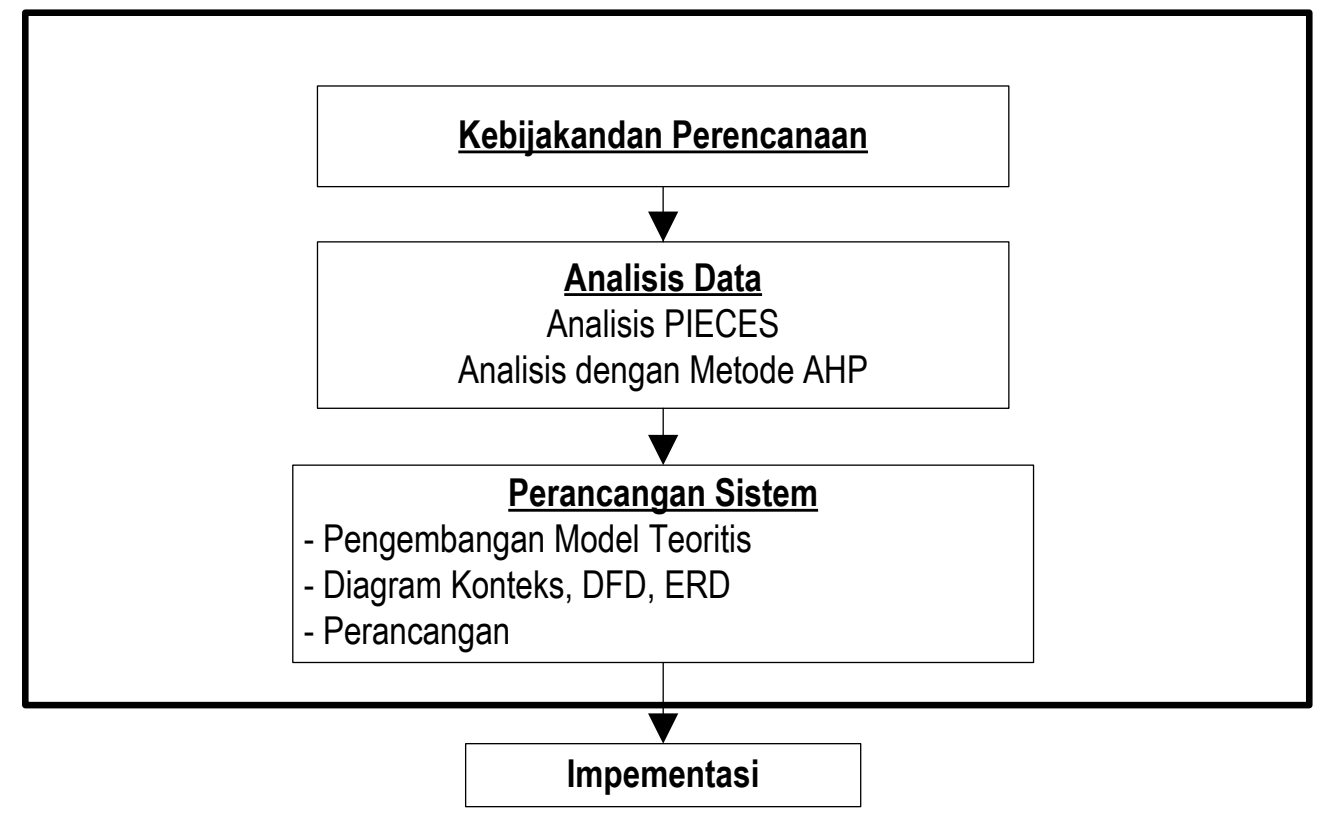

\section{Gambar 3.1 Flowchart Penelitian}

Kegiatan yang akan dilakukan pada bab analisa dan perancangan dapat dilihat pada gambar diatas, yaitu dimulai dengan penentuan kebutuhan yang digolongkan pada tahapan kebijakan dan perencanaan, kemudian tahapan selanjutnya adalah tahapan Analisa data, dan selanjutnya yaitu melakukan tahapan akhir yaitu tahapan perancangan sistem. 


\section{PEMBAHASAN DAN IMPLEMENTASI}

\subsection{Pembahasan}

Penerapan sistem pada keadaan yang sebenarnya dapat dikatakan sebagai bentuk implementasi, melalui tahapan ini nantinya akan diketahui apakah sistem yang telah dibangun benar-benar dapat berjalan sesuai dengan tujuan yang diharapkan atau tidak.l

\subsubsection{Struktur Hirarki}

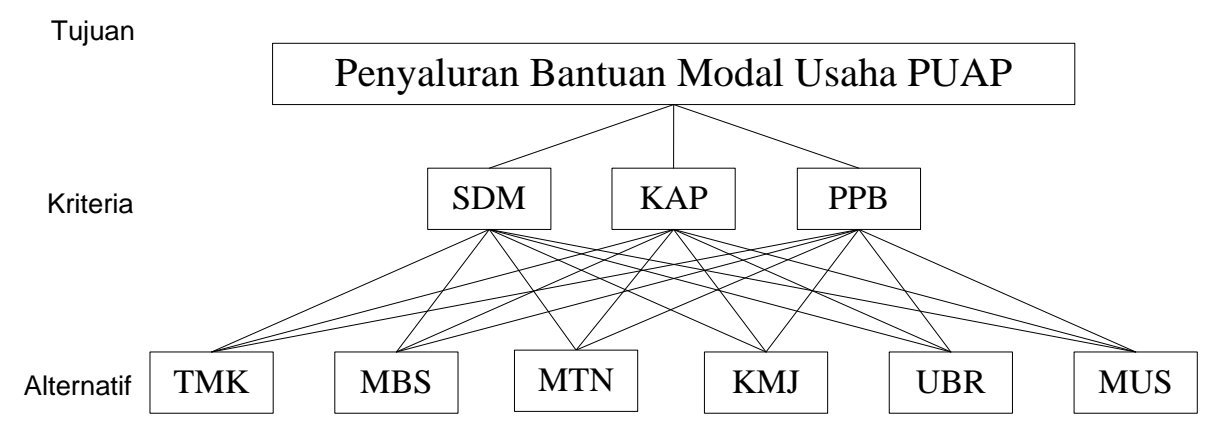

Gambar 4.1 Hirarki Proses Penyaluran Bantuan Modal Usaha PUAP

Dari Gambar 4.1 diatas dapat diketahui bahwa level pertama merupakan level Tujuan: Penyaluran Bantuan Modal Usaha PUAP. Level kedua adalah kriteria untuk dapat mencapai tujuan utama. Sementara level ketiga merupakan alternatif dari yang digunakan, untuk level kriteria dan alternatif

\subsection{Implementasi}

Tahapan implementasi membahas atau menceritakan keadaan sistem pendukung keputusan yang telah dibangun akan diceritakan pada tahapan ini, sehingga akan diketahui bagaimana proses kerja dari sistem pendukung keputusan tersebut. Dan melakukan penjelasan-penjelasan dari setiap tampilan atau bentuk dari layar monitor sebagai interface antara user dengan sistem yang sudah dirancang pada aplikasi ini. Berikut ini merupakan penjelasan-penjelasan dari setiap user interface aplikasi sistem pendukung keputusan ini:

1. Perbandingan Kriteria

Perbandingan kriteria merupakan form yang digunakan untuk menginputkan hasil quisioner dengan skala perbandingan antar kriteria yang digunakan untuk melakukan proses perhitungan AHP pada sistem ini. Perbandingan ini nantinya digunakan untuk mengetahui hasil perangkingan pada proses penentuan prioritas global untuk pengambilan keputusan pada penyaluran bantuan modal usaha pengembangan usaha agribisnis pedesaan di BP2KP Kabupaten Indragiri Hilir.

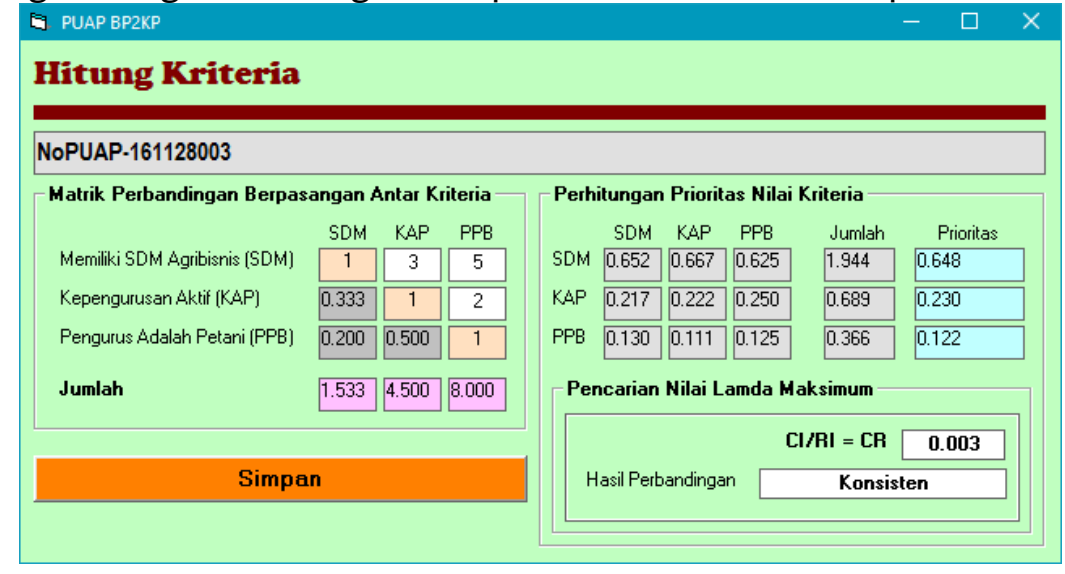

Gambar 4.2 Perbangdingan Kriteria

Ramadona, Kombinasi Metode Analytical Hierarchy Process (AHP) Dan Metode Simple Additive Weighting (SAW) Pada Penilaian Kinerja Dosen 
Form perbandingan kriteria ini juga menampilkan hasil perhitungan prioritas nilai kriteria sehingga diketahui bobot prioritas dari setiap kriteria, selain dari itu, form ini memperlihatkan nilai konsistensinya.

2. Perbangdingan Alternatif

Perbandingan alternatif adalah form yang digunakan untuk melakukan proses perhitungan AHP untuk alternatif berdasarkan hasil quisioner, form ini jumlahnya sesuai dengan jumlah kriteria yang ada, karena untuk memberikan keputusan penyaluran bantuan modal usaha pengembangan usaha agribisnis pedesaan di BP2KP Kabupaten Indragiri Hilir, maka setiap alternatif harus dibandingankan dengan berdasarkan kriteria yang ada. Proses entri yang ada pada form ini sama dengan form kriteria yaitu cukup inputkan nilai hasil quisioner pada kolom matrik perbandingan berpasangan antar alternatif. Maka selanjutnya secara otomatis akan menampilkan hasil perhitungan prioritas nilai perbandingan alternatif.

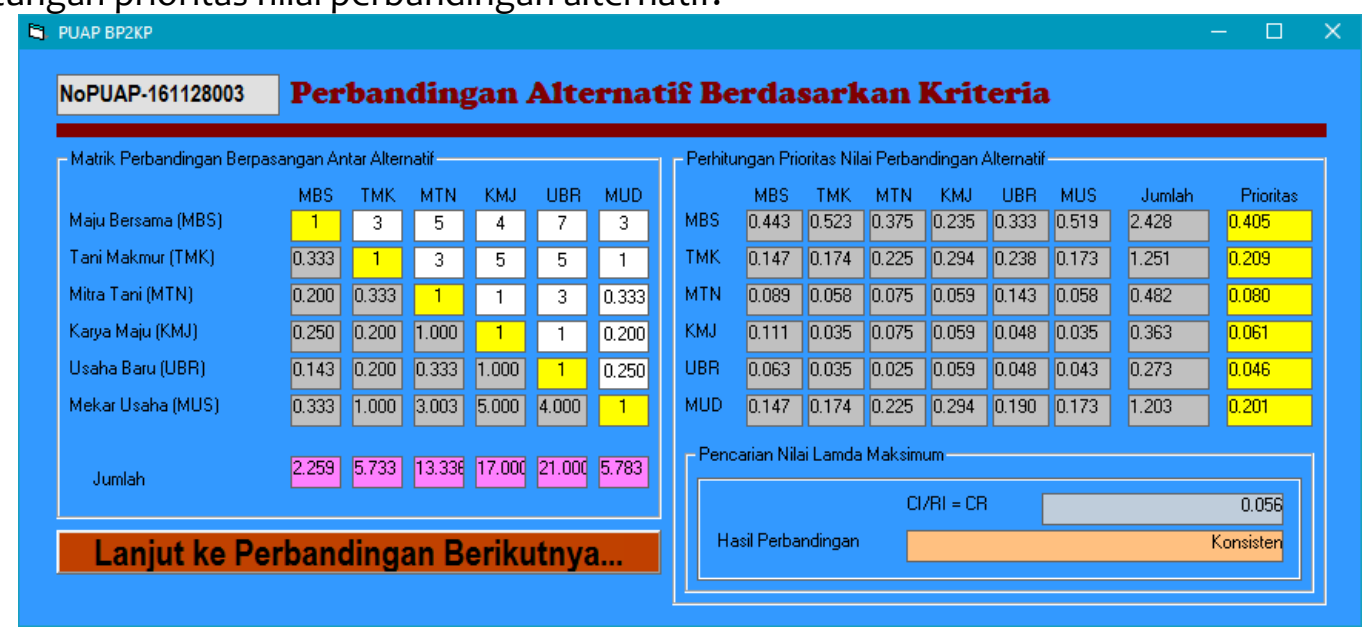

Gambar 4.3 Perbangdingan Alternatif

Proses perbandingan antar alternatif berdasarkan kriteria, hal pertama yang dilakukan memilih alternatif yang akan dibandingkan. Pada kasus ini ada tiga alternatif yang dibandingkan untuk setiap perbanndingannya. Setelah dilakukan pengisian matrik perbandingan, selanjutnya lakukan perbandingan alternatif pada setiap keriteria yang ada dengan menekan tombol lanjutkan perbandingan berikutnya. Sampai timbul form hasil perhitungan atau dapat disebut juga perhitungan prioritas global.

3. Prioritas Global

Prioritas global menunjukkan nilai bobot dari dari setiap pebandingan ataupun hasil dari perkalian matriks yang telah dilakukan sebelumnya, baik nilai bobot prioritas kriteria maupun bobot prioritas perbandingan antar alternatif berdasarkan kriteria. Dari nilai-nilai bobot prioritas alternatif yang ada dikali matrikkan dengan nili bobot prioritas yang ada sehingga mengasilkan suatu nilai yang disebut juga nilai perangkingan untuk setiap alternatif. Nilai-nilai tersebut digunakan sebagai bobot untuk menentukan alternatif mana yang dapat dijadikan sebagai rekomendasi dalam sistem pendukung keputusan ini. Hasil rekomendasi diperlihatkan dalam bentuk rangking dan juga merupakan informasi yang ada pada form ini. Alternatif yang memiliki nilai tertinggi dijadikan sebagai bahan rekomendasi keputusan penyaluran bantuan modal usaha pengembangan usaha agribisnis pedesaan di BP2KP Kabupaten Indragiri Hilir. 


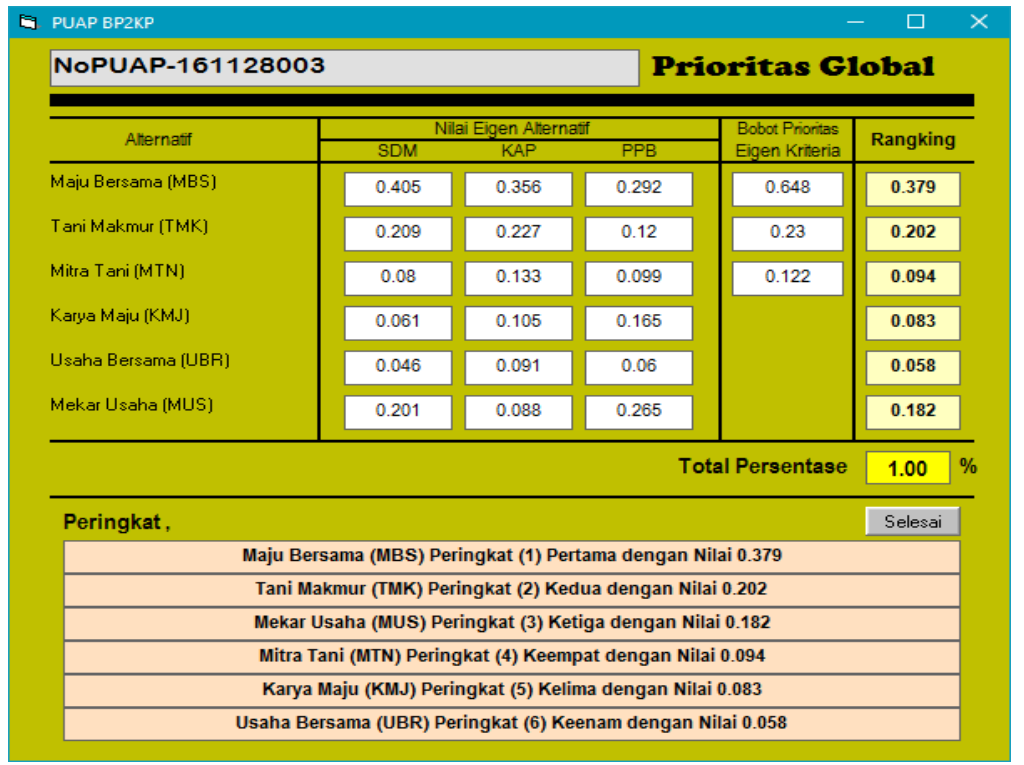

Gambar 4.4 Prioritas Global

Hasil perhitungan yang telah dilakukan sebelumnya maka dapat diketahui bahwa urutan prioritas global/peringkat keputusan penyaluran bantuan modal usaha pengembangan usaha agribisnis pedesaan di BP2KP Kabupaten Indragiri Hilir yaitu sebagaimana dijelaskan berikut:

1. Maju Bersama adalah rangking pertama dengan nilai prioritas 0.379 atau $37,9 \%$.

2. Tani Makmur berada pada rangking keputusan nomor dua dengan nilai prioritas 0.202 atau $20,2 \%$.

3. Mekar Usaha dengan nilai prioritas keputusan sebesar 0.182 atau $18,2 \%$ merupaka rangking atau peringkat ke tiga dari hasil rekomendasi keputusan.

4. Mitra Tani berada di peringkat ke empat dengan nilai prioritas/eigen 0.094 atau $9,4 \%$.

5. Karya maju berada di rangking ke lima dengan nilai eigen prioritas sebesar 0.083 atau $8,3 \%$. Dan

6. Rekomendari yang terakhir dalam pengambilan keputusan ini yaitu Usaha Bersama dengan nilai eigen 0.058 atau $5,8 \%$.

Berdasarkan rangking yang diperoleh dari hasil perhitungan dengan metode AHP dalam sistem pendukung keputusan ini, maka yang menjadi rekomendasi di tingkat pertama untuk diperioritaskan sebagai penerima bantuan modal usaha pengembangan usaha agribisnis pedesaan di BP2KP Kabupaten Indragiri Hilir adalah Maju Bersama adalah rangking pertama dengan nilai prioritas 0.379 atau $37,9 \%$.

\section{KESIMPULAN}

Berdasarkan hasil penelitian diperoleh pemilihan penerima penyaluran bantuan modal usaha pengembangan usaha agribisnis pedesaan di BP2KP Kabupaten Indragiri Hilir yang menggunakan metode Analytical Hierarchy Process (AHP), maka di dapat beberapa kesimpulan yaitu:

Hasil perhitungan yang didapat bahwa Gapoktan yang menjadi prioritas utama untuk dijadikan sebagai bahan rekomendasi penerima penyaluran bantuan modal usaha pengembangan usaha agribisnis pedesaan di BP2KP Kabupaten Indragiri Hilir yaitu Maju Bersama adalah rangking pertama dengan nilai prioritas 0.379 atau $37,9 \%$.

Pada penelitian ini, setelah dilakukan perhitungan maka kriteria yang memiliki nilai eigen tertinggi adalah Memiliki SDM untuk Mengelola Usaha Agribisnis (SDM) dengan nilai 0.648 atau $64,8 \%$.

Berdasarkan analisa dilakukan, metode Analytical Hierarchy Process (AHP) dapat digunakan sebagai metode dalam Sistem Pendukung Keputusan untuk penyaluran bantuan modal usaha pengembangan usaha agribisnis pedesaan di BP2KP Kabupaten Indragiri Hilir. 
Berdasarkan hasil kesimpulan dari sistem pendukung keputusan penyaluran bantuan modal usaha pengembangan usaha agribisnis pedesaan di BP2KP Kabupaten Indragiri Hilir, bahwa saran yang dapat diberikan yaitu:

Penelitian ini dapat dijadikan sebagai bahan rujukan oleh kepala BP2KP Kabupaten Indragiri Hiir dalam menentukan Gapoktan penerima bantuan penyaluran modal usaha berdasarkan kriteria yang telah ditetapkan.

Penelitian ini hanya menganalisa dan menguji hasil perhitungan metode AHP untuk pemilihan Gapoktan penerima bantua modal usaha dengan menggunakan enam alternatif sebagai acuan dalam penilaian, untuk itu diharapkan kepada peneliti selanjutnya yang menjadikan penelitian ini sebagai rujukan agar dapat melakukan perancangan sistem pendukung keputusan yang lebih baik yang dapat digunakan untuk melakukan penilaian terhadap penyaluran bantuan modal usaha pengembangan usaha agribisnis pedesaan di BP2KP Kabupaten Indragiri Hilir.

\section{REFERENSI}

Hartono, J. (2005). Pengenalan Komputer. Yogyakarta: Andi.

Herdiyanti, A., \& Widianti, U. D. (2013). Pembangunan Sistem Pendukung Keputusan Rekrutment Pegawai Baru di PT. ABC. Jurnal Ilmiah Komputer dan Informatika (KOMPUTA) , 49-56.

Iwan, R., \& Lirien, O. (2012). Sistem Pendukung Keputusan Pemilihan Karyawan Berprestasi Berdasarkan Kinerja Menggunakan Metode Analytical Hierarchy Process. Seminar Nasional Informatika (pp. -). Yogyakarta: -.

Tominanto. (2012). Sistem Pendukung Keputusan Dengan Metode Analytical Hierarchy Process (AHP) Untuk Penentuan Prestasi Kinerja Dokter Pada RSUD. Sukoharjo. INFOKES , 1-15. 